\title{
The influence of the moisture content in historical masonry walls on the load bearing capacity
}

\author{
Monika Siewczynska ${ }^{1, *}$, Barbara $\mathrm{Ksit}^{1}$ \\ ${ }^{1}$ Poznan University of Technology, Piotrowo 5, 60-965 Poznan, Poland
}

\begin{abstract}
The moisture content in historical masonry walls, particularly on the ground floor, caused by i.e. lack of damp insulation, is a phenomenon of common occurrence. It is usually analysed in terms of mycological changes, thermal insulation and frost damage. The paper discusses the influence of the increased moisture content on the weight and load bearing capacity of the structure. The determination of moisture content in masonry elements, performed during the inspection of the building, provides information from which an increase in the structure's weight can be defined. Reliable tests for the moisture content and compressive strength of masonry and mortar components are invasive, and the number of testing in historical buildings should be limited to the minimum necessary to preserve their vintage nature. As a result, the received overall picture of the work of masonry may not be consistent with its actual state since historical buildings could have been rebuilt or repaired, and consequently, contain masonry conversions made of various materials with different properties. Absorbability can serve here as an example as it is a factor that disrupts a reliable determination of load bearing capacity values of masonry structures. The article attempts to determine the change in load bearing capacity of a moist masonry structure compared to the original - in the air-dry state - for various types of historical masonry and mortar components. The main influence analysed was due to capillary action, whereas the effect of other sources of moisture, i.e. salinity, was excluded.
\end{abstract}

\section{Moisture content in masonry walls}

Structural dampness in masonry walls has a destructive effect not only on the usability of rooms in the building, i.e.:

- microclimate,

- conditions conducive to the development of mould fungi,

- deterioration of thermal insulation properties,

but also for the load bearing capacity of masonry materials.

Masonry walls began to be protected against moisture content in the 1920s [1], however, today in many cases the applied solutions have ceased to be effective.

\footnotetext{
${ }^{*}$ Corresponding author: monika.siewczynska@put.poznan.pl
} 
The sources of moisture are inside and outside of buildings, also in the ground. Although there are many methods to test the degree of moisture content, they do not always provide accurate information about the conditions found across the whole wall [1]. It is particularly difficult to test the moisture content in historical masonry walls of considerable thickness, primarily in the situation when conservation restrictions prevent destructive testing.

\section{Materials and methods of moisture protection applied at the beginning of the 20th century}

Foundations in buildings from the beginning of the 20th century were placed on dry sand, made of natural stone, well-burnt bricks or concrete. The destructive influence of water was determined in the aspect of loosening the soil structure -its reduced compressive strength and increased moisture penetration into the building due to the porosity of construction materials. The moisture penetration was limited by using a drainage system introduced before constructing the building. Drains with a diameter of $6.5 \mathrm{~cm}$ were installed on both sides of foundations, below the foundation level. Water was drained to a reservoir, a small river, a pond, if they were nearby, or to a well, from where it was later collected for domestic purposes. Previously, buildings were protected against soaking and permeating water with the use of horizontal insulation layers made of $[2,12]$ :

- asphalt mass with a thickness of $0.5 \div 1.5 \mathrm{~cm}$ in the proportions: $1 / 2 \div 1$ part of tar and 2 parts of sand,

- asphalt plates,

- bituminous roofing felt (used for covering roofs) laid in two layers,

- oily cement mortar in the proportions: 1 part of cement and $1 / 2 \div 1$ part of sand $4 \div 5 \mathrm{~cm}$ thick, cultivated with water and sheltered from the sun for 4-6 days,

- two layers of stones or three layers of bricks laid in pure cement mortar with dampproofing additives and watertight admixtures

and less frequently:

- iron sheets shielded from two sides with cement mortar,

- lead plates,

- glass,

- lime with melted lard in the proportions: 1 part of lime and 5 parts of lard,

- cement with paraffin waste,

- cement with grey soap.

Horizontal insulation in non-basement buildings was placed below the level of the floor beams' support. In buildings with basements, part of insulation was laid horizontally and part vertically, including the air layer placed closer to the outer side of the wall. The effectiveness of the drying process with air layers was ensured by vertical channels, which were led out above the terrain. Horizontal insulation was sometimes provided in two places: below the floor and below the ground floor.

Foundation walls made of stone were covered with a layer of brickwork. Between these layers, a gap was left that was connected by several openings to the inner room and by channels and chimneys to the outside air (at the top of these walls) [3].

The vertical surface of walls was protected against the external environment with clay cladding that often came from excavations. This layer was a continuous coating and together with the drainage and channels described above formed a damp proofing system. Subsequent renovation or construction works carried out in the streets in the vicinity of the buildings quite often damaged one of the elements (by covering the drying channels, removing the clay layer and, above all, damaging the drainage system). 
Wide eaves and specially structured plinths provided an additional protection against moisture from rainwater. The prevailing recommendation was to use the same materials as for underground parts: the most durable and non-porous. There were used natural stones, especially granite, and of artificial materials - clinker masonry laid in cement mortar, alternatively - burnt or very well burnt bricks [2]. The height of plinth insulation was comparable to similar protection in wooden buildings. Even earlier rules for the construction of wooden houses (from the end of the 18th century) recommended that the plinth should be raised (from the same material as the foundation, e.g. stone) to the height of $1 / 2$ elbow [4], i.e. approx. $0.3 \mathrm{~m}$.

\section{Water absorption rates in masonry walls}

The degrees of moisture content, in percentage relation to the value of mass moisture content, are as follows [10]:

- permissible moisture content: $0-3 \%$,

- increased moisture content: $3-5 \%$,

- average moisture content: $5-8 \%$,

- high moisture content $8-12 \%$,

- wet masonry wall: $>12 \%$.

In historical buildings, materials of different porosity and absorbability were used for laying foundation walls [2 and 3]. Table 1 presents the results of moisture content and compressive strength tests of bricks from the buildings of Poznań forts [5].

Table 1. Moisture content andcompressive strength parameters of bricks from Fort Rauch in Poznań; source: [5].

\begin{tabular}{|c|c|c|}
\hline \multirow{2}{*}{ No. } & Mass moisture & Compressive strength \\
\cline { 2 - 3 } & {$[\%]$} & {$[\mathrm{MPa}]$} \\
\hline 1 & $5.3 \%$ & 18.3 \\
\hline 2 & $2.3 \%$ & 35.5 \\
\hline 3 & $15 \%$ & - \\
\hline 4 & $2.2 \%$ & 20.8 \\
\hline 5 & $5.0 \%$ & 17.9 \\
\hline 6 & $0.9 \%$ & 29.8 \\
\hline 7 & $4.8 \%$ & 16.2 \\
\hline 8 & $6.7 \%$ & 22.5 \\
\hline 9 & $2.4 \%$ & 31.7 \\
\hline 10 & $5.2 \%$ & - \\
\hline 11 & $18.9 \%$ & 17.1 \\
\hline 12 & $8.2 \%$ & 29.3 \\
\hline
\end{tabular}

The origin and age of the tested bricks were not the same. It is possible that some of them came from earlier demolition or reconstruction works carried out in the forts. The number of samples was small due to conservation restrictions. There were few more samples with the permissible moisture content, but the dispersion of moisture content values (Fig. 1) demonstrates that none of the moisture content degrees can be excluded from analysing. 


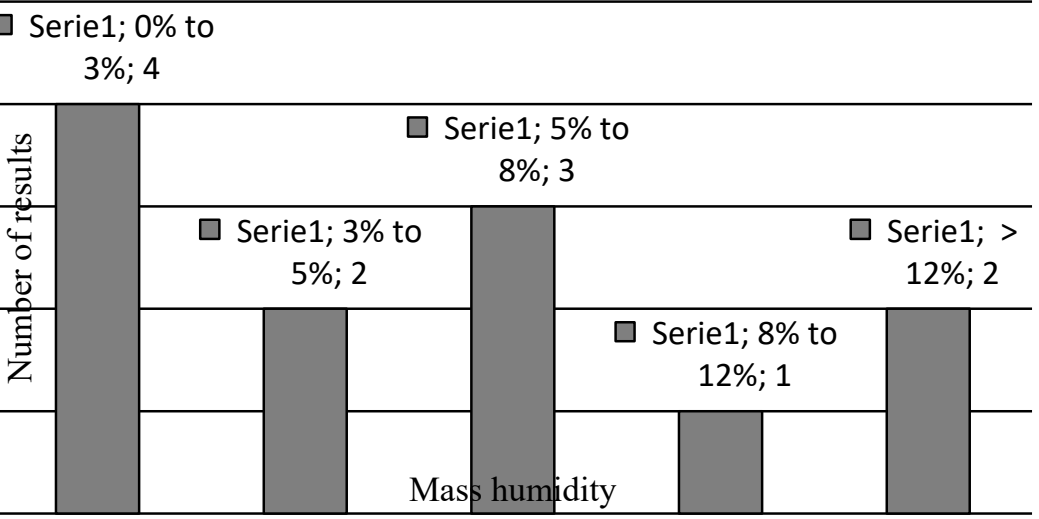

Fig. 1. Number of samples with mass moisture in individual ranges obtained on the basis of the test results given in Table 1 .

The distribution of moisture content in the masonry wall changes with its height. The results presented below come from the research conducted during the renovation of the Knight's Academy building in Kołobrzegdating back to the beginning of the 18th century. Table 2 shows the change in moisture content in the masonry wall where capillary action was found coexisting with other moisture sources, such as:

- hygroscopic moisture associated with the occurrence of salinitycaused by concentrations of salts in groundwater; due to the process of saltcrystallisation it is related to damage to bricks and plaster,

- moisture penetrating from the side and hygroscopic moisture content.

Table 2. Measurements of the moisture content in the wall of the Knight's Academy building at different heights; source: [11].

\begin{tabular}{|c|c|c|}
\hline \multirow{3}{*}{ Profile } & Sampling height & Primary moisture content \\
\cline { 2 - 3 } & {$[\mathrm{cm}]$} & {$[\%]$} \\
\hline \multirow{4}{*}{ M2 } & 30 & 10.40 \\
\cline { 2 - 3 } & 60 & 6.01 \\
\cline { 2 - 3 } & 90 & 4.93 \\
\cline { 2 - 3 } & 120 & 2.81 \\
\hline \multirow{4}{*}{ M3 } & 150 & 1.00 \\
\cline { 2 - 3 } & 30 & 14.73 \\
\cline { 2 - 3 } & 60 & 11.47 \\
\cline { 2 - 3 } & 90 & 12.32 \\
\cline { 2 - 3 } & 120 & 14.85 \\
\hline \multirow{4}{*}{ M7 } & 150 & 10.68 \\
\cline { 2 - 3 } & 180 & 18.19 \\
\cline { 2 - 3 } & 50 & 14.55 \\
\cline { 2 - 3 } & 100 & 7.84 \\
\hline
\end{tabular}




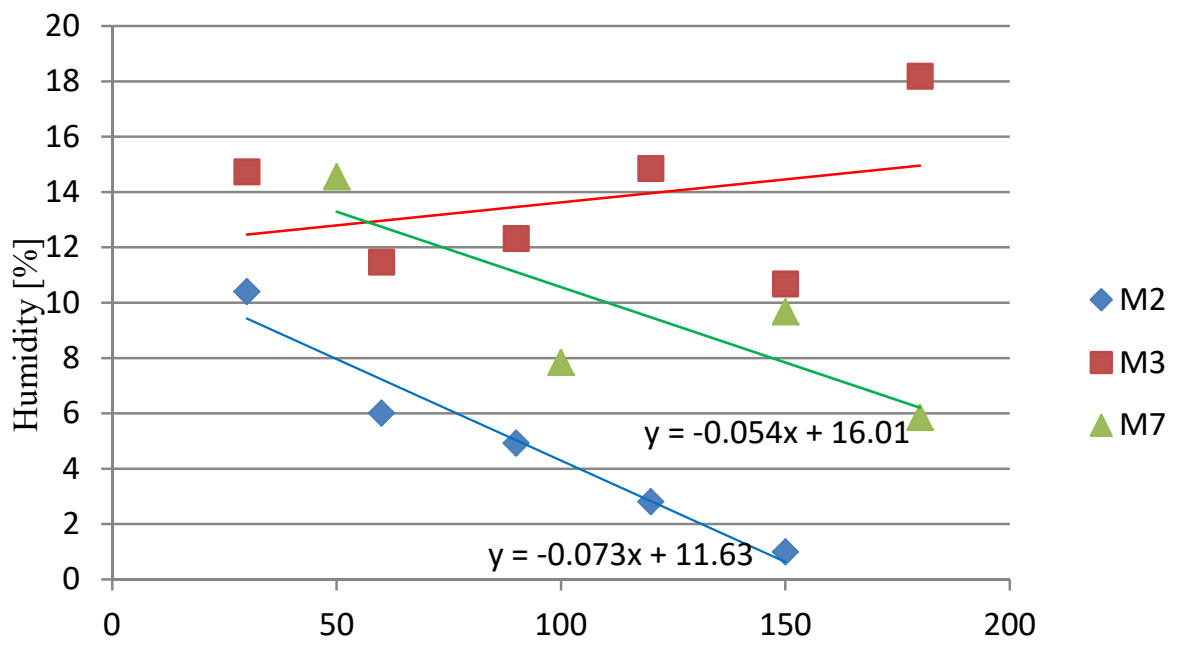

Distance from the bottom of the wall [\%]

Fig. 2. Trend lines of changes in moisture content at the height of the wall; source: [11].

The distribution of changes in moisture content is presented in Fig. 2. Measurements in M3 profile provided different data compared to measurements in profiles M2 and M7 they could have been affected by other factors causing the wall to get wet at this height. On the basis of results for profiles M2 and M7, the exemplary average value of change in moisture content at the height of the wall was estimated. Further analysis was based on the assumed correlation:

$$
y=-0.06 x+b
$$

where $x$ is the height measured from the bottom of the wall, and $y$ represents the moisture content. Parameter $\mathrm{b}$ was adopted variably depending on the assumed moisture content at $1.5 \mathrm{~m}$ from the bottom of the wall. The computational simulations described in the next chapter were carried out according to the following assumptions:

- although the literature provides information [6] that capillary action can be found several meters above the ground level, in these analyses the height was limited to approx. $1.8 \mathrm{~m}$ above the source of moisture, it was assumed that the plinth was $0.3 \mathrm{~m}$, thus, the moisture content due to capillary action was assumed in the ground floor wall at $1.5 \mathrm{~m}$ from the floor level,

- all degrees of moisture content were included (as described in point 2, in the air-dry state) at $1.5 \mathrm{~m}$ calculating from the formula (1), the disappearance of moisture content above $1.5 \mathrm{~m}$, the distribution of moisture content is given in Table 3

- negative moisture content values (lower than the one in reference condition) resulting from calculations based on the formula (1) were excluded,

- on the basis of Hoła and Matkowski considerations [1] it was assumed that the moisture content of the wall surface was a few percentage lower than inside its cross-section - for the simulation the plaster moisture content was $2 \%$ lower than the moisture content in the masonry wall. Hygroscopic moisture was not included [11]. 
Table 3. Simulation of the distribution of moisture content in the wall applied in the analyses.

\begin{tabular}{|c|c|c|c|c|c|}
\hline \multirow{2}{*}{$\begin{array}{l}\text { Distance from the } \\
\text { bottom of the wall } \\
{[\mathrm{cm}]}\end{array}$} & \multicolumn{5}{|c|}{ Moisture content at $1.5 \mathrm{~m}$ [\%] } \\
\hline & 1 & 3 & 5 & 8 & 12 \\
\hline 310 & - & - & - & - & 2.4 \\
\hline 300 & - & - & - & - & 3.0 \\
\hline 290 & - & - & - & - & 3.6 \\
\hline 280 & - & - & - & 0.2 & 4.2 \\
\hline 270 & - & - & - & 0.8 & 4.8 \\
\hline 260 & - & - & - & 1.4 & 5.4 \\
\hline 250 & - & - & - & 2.0 & 6.0 \\
\hline 240 & - & - & - & 2.6 & 6.6 \\
\hline 230 & - & - & 0.2 & 3.2 & 7.2 \\
\hline 220 & - & - & 0.8 & 3.8 & 7.8 \\
\hline 210 & - & - & 1.4 & 4.4 & 8.4 \\
\hline 200 & - & - & 2.0 & 5.0 & 9.0 \\
\hline 190 & - & 0.6 & 2.6 & 5.6 & 9.6 \\
\hline 180 & - & 1.2 & 3.2 & 6.2 & 10.2 \\
\hline 170 & - & 1.8 & 3.8 & 6.8 & 10.8 \\
\hline 160 & 0.4 & 2.4 & 4.4 & 7.4 & 11.4 \\
\hline 150 & 1.0 & 3.0 & 5.0 & 8.0 & 12.0 \\
\hline 140 & 1.6 & 3.6 & 5.6 & 8.6 & 12.6 \\
\hline 130 & 2.2 & 4.2 & 6.2 & 9.2 & 13.2 \\
\hline 120 & 2.8 & 4.8 & 6.8 & 9.8 & 13.8 \\
\hline 110 & 3.4 & 5.4 & 7.4 & 10.4 & 14.4 \\
\hline 100 & 4.0 & 6.0 & 8.0 & 11.0 & 15.0 \\
\hline 90 & 4.6 & 6.6 & 8.6 & 11.6 & 15.6 \\
\hline 80 & 5.2 & 7.2 & 9.2 & 12.2 & 16.2 \\
\hline 70 & 5.8 & 7.8 & 9.8 & 12.8 & 16.8 \\
\hline 60 & 6.4 & 8.4 & 10.4 & 13.4 & 17.4 \\
\hline 50 & 7.0 & 9.0 & 11.0 & 14.0 & 18.0 \\
\hline 40 & 7.6 & 9.6 & 11.6 & 14.6 & 18.6 \\
\hline 30 & 8.2 & 10.2 & 12.2 & 15.2 & 19.2 \\
\hline 20 & 8.8 & 10.8 & 12.8 & 15.8 & 19.8 \\
\hline 10 & 9.4 & 11.4 & 13.4 & 16.4 & 20.4 \\
\hline 0 & 10.0 & 12.0 & 14.0 & 17.0 & 21.0 \\
\hline
\end{tabular}

\section{Load bearing capacity of masonry walls in historical buildings}

The assortment of masonry materials used at the beginning of the 20th century cannot be classified as vast. The walls of residential buildings were erected from solid ceramic bricks of middle-quality class $3.5,5,7.5$ (according to today's criteria) [7]. It was common to use lime mortar (mix type: M 0.3 or M 0.6 ) or lime mortar with addition of cement (estimated mix type: M 2 to M 3) at selected locations: cellar walls or pillars [7]. The calculations did not take into account the impact of chemicals on masonry materials, however, it should be noted that mortar may contain many minerals, which, although not destructive, under the influence of salts and solutions corrode, and can even disintegrate completely (e.g. mica) [13].

The load-bearing capacity of the wall laid in mainly lime mortar should be determined according to the standards included in PN-67/B-03002, because it was the last code giving compressive strength values for brick walls in lime mortar [8]. Matysek [8] holds that the 
values of load bearing capacity calculated according to the modified L. J. Oniszczyk formula (provided in the 1967 standard):

$$
f_{\text {mean }}=\frac{100+f_{b}}{100+3.3 \cdot f_{b}} \cdot \frac{\frac{f_{m}}{f_{b}}+0.2}{\frac{f_{m}}{f_{b}}+0.6} \cdot f_{b}
$$

give overestimated results and they should be reduced by $20 \%$. In the formula (2) $f_{b}$ is class of brick $\left[\mathrm{kG} / \mathrm{cm}^{2}\right], f_{m}$ is mortar mix type $\left[\mathrm{kG} / \mathrm{cm}^{2}\right]$, and $f_{\text {mean }}$ is mean compressive strength value of a masonry wall.

Table 4 shows the calculated values for the selected combinations $f_{b}$ and $f_{m}$.

Table 4. Calculated values of $f_{\text {mean }}$ for the selected combinations $f_{b}$ and $f_{m}$.

\begin{tabular}{|c|c|c|c|c|}
\hline $\boldsymbol{f}_{\text {mean }}\left[\mathbf{k G} / \mathbf{c m}^{2]}\right.$ & \multicolumn{4}{|c|}{$\boldsymbol{f}_{\boldsymbol{b}}\left[\mathbf{k G} / \mathbf{c m}^{\mathbf{2}]}\right.$} \\
\hline $\boldsymbol{f}_{\boldsymbol{m}}\left[\mathbf{k G} / \mathbf{c m}^{2]}\right.$ & 100 & 75 & 50 & 35 \\
\hline 20 & 18.6 & 16.3 & 13.6 & - \\
\hline 6 & - & 12.4 & 10.0 & 8.4 \\
\hline 3 & - & - & 8.9 & 7.3 \\
\hline
\end{tabular}

The parameters adopted are lower than the parameters obtained from the tests (Table 1) [5], showing that historical bricks can be classified as bricks with a strength class of at least $15 \mathrm{MPa}$. Stryszewska [9] provides the results of compressive strength test for bricks in the dry state and the state of full water saturation. It results from the survey that the moisture content reduced compressive strength by an average of 8 to $12 \%$. Subsequently, the simulations were supplemented with an additional class of bricks $-15 \mathrm{MPa}$.

\section{Change in load bearing capacity of brick walls after exposure to moisture}

The following assumptions were used to simulate the change in load-bearing capacity of the wet wall in a multi-family residential building:

- dense urban development,

- two over-ground utility floors and a non-usable attic and a basement,

- wooden roof with a slope of $17^{\circ}$ covered with roofing paper on the roof boarding, the knee wall $25 \mathrm{~cm}$ thick and $1 \mathrm{~m}$ high,

- basement height $-2.5 \mathrm{~m}$, ground floor height $-4.2 \mathrm{~m}$, floor height $-3.3 \mathrm{~m}$, attic height $2.5 \mathrm{~m}$,

- walls on the ground floor and the first floor made of solid ceramic bricks $-38 \mathrm{~cm}$ thick, attic walls $-25 \mathrm{~cm}$ thick, basement walls $-54 \mathrm{~cm}$ thick,

- windowsill height $-0,9 \mathrm{~m}$, window height $-2.0 \mathrm{~m}$ (on the ground floor $-2.9 \mathrm{~m}$ ), lintel height $-0.4 \mathrm{~m}$, assumed window pillar width $-1.2 \mathrm{~m}$, assumed window width $-1.2 \mathrm{~m}$, thus, assumed impact width $-2.4 \mathrm{~m}$,

- klein's ceiling over the basement, wooden ceilings over higher floors,

- construction loads in accordance with the standards in force in 1964,

- load bearing capacity calculations carried out in compliance with standards included in PN-67/B-03002, assuming the load-bearing capacity of the wall according to Table 4,

- the weight of ground floor walls increased according to the calculations presented in Table 3. 
The results of load bearing capacity provided in Table 5 are the values of percentage utilisation of the ground floor window pillar's load-bearing capacity. The table includes only the calculation results for which load bearing capacity values were exceeded. The permissible load bearing capacity was exceeded for lower classes of bricks and mortar types.

Table 5. Percentage utilisation of load bearing capacity for various degrees of moisture content.

\begin{tabular}{|c|c|c|c|c|c|}
\hline \multirow{2}{*}{$\boldsymbol{f}_{\boldsymbol{b}}, \boldsymbol{f}_{\boldsymbol{m}}$} & \multicolumn{5}{|c|}{ Moisture content at 1.5 $\mathbf{m}[\mathbf{\%}]$} \\
\cline { 2 - 6 } & 1 & 3 & 5 & 8 & 12 \\
\hline 150,20 & 66 & 66 & 66 & 66 & 67 \\
\hline 100,20 & 81 & 81 & 81 & 82 & 82 \\
\hline 75,20 & 93 & 93 & 93 & 93 & 94 \\
\hline
\end{tabular}

Slight differences were observed in the values of load bearing capacity of the window pillar in the simulations carried out.

\section{Summary}

The variety of structural moisture protection methods from the beginning of the 20th century proves that the awareness that buildings should be insulated from moisture was prevalent. The lack or ineffectiveness of the insulation and the resulting dampness of masonry walls is today the most common problem found while renovating historical buildings. Dense development and changes in the surrounding infrastructure as well as repair and reconstruction works have led to damage or removal of old moisture barriers preventing proper restoration.

The tests analysed in the paper focused only on the degree of moisture content in walls and the distribution of moisture content resulting from capillary action. The chemical decomposition of both ceramic products and mortar types was not analysed.

The load-bearing capacity of walls depends on the compressive strength of bricks and mortar, however, the correct assumption of these values is difficult. Buildings under conservation restrictions cannot be used to collect a large number of destructive testing samples, and non-destructive testing does not always provides sufficient information (often the data is limited to surface parameters). Considering bricks and mortar, data with low compressive strength prevails in the literature, although a few available experimental studies give information about higher values. The results obtained from the simulations described in the paper show that for bricks class $5 \mathrm{MPa}$ and lower laid in lime mortar, the load-bearing capacity of the window pillar would be exceeded even for walls in the air-dry state. This suggests the conclusion that the parameters of bricks and mortars used at the beginning of the 20th century included in the literature may be insufficient, and the actual values of strength parameters of masonry elements may have been more diversified in the old days.

\section{References}

1. J. Hoła, Z. Matkowski, (Wybrane problemy dotyczace zabezpieczeń przeciwwilgociowych ścian $w$ istniejacych obiektach murowanych, XXIV Konferencja Naukowo-Techniczna Awarie Budowlane, 73-92 2009)

2. S. Turczynowicz, (Budownictwo wiejskie, Nakładem Księgarni Rolniczej, reprint Warszawa, 1922) 
3. K. Iwanicki, (Budownictwo wiejskie, Nakład Księgarni Leona Idzikowskiego, Kijów reprint Warszawa 1917)

4. Budowanie wieyskie dziedzicom dobr y possessorom toż wszystkim iakążkolwiek zwierzchność po wsiach i miasteczkach mającym do uwagi y praktyki podane, Nakładem i Drukiem Michała Grölla, Warszawa, reprint Lwów, 1782)

5. J. Jasiczak, M. Kanoniczak, T. Kanoniczak, (Wpływ dawnego Fortu Rauch na lokalizacje budynku Wydziatu Budownictwa Lądowego Politechniki Poznańskiej, Rewitalizacja obszarów zurbanizowanych, praca zbiorowa / red. Wiesław Buczkowski, Anna Szymczak-Graczyk, Wydawnictwo Zarządu oddziału PZITB w Poznaniu 71-85 (2016)

6. J. Jasieńki, Z. Matkowski, (Zasolenie $i$ zawilgocenie murów ceglanych $w$ obiektach zabutkowych-diagnostyka, metodyka badań, techniki rehabilitacji, Wiadomości Konserwatorskie 14, 2003)

7. L. Macieik, Wzmacnianie konstrukcji starych budynków, http://abc-sciany.pl, access on April 2018

8. P. Matysek, (Metody określania wytrzymałości na ściskanie murów ceglanych w obiektach zabytkowych, Inżynieryjne Problemy Odnowy Staromiejskich Zespołów Zabytkowych, IV Konferencja Naukowo-Techniczna REW-INŻ '98, Kraków, 1998)

9. T. Stryszewska, Materiały Ceramiczne, 66,1 81-87 (2014)

10. Wytyczne WTA 4-11-02 Messung der Feuchte von mineralischemBaustoffen

11. B. Ksit, K. Tabiś, (Wtaściwa diagnostyka zawilgocenia budynku gwarantem trwałości hydrorewitalizacji Konferencja Naukowo-TechnicznaRenowacja budynków i modernizacja obszarów zabudowanych, Zielona Góra 2018)

12. Ksit B., Monczyński B., Renowacja zawilgoconych budynków. Osuszanie przegród budowlanych oraz usuwanie szkód spowodowanych nadmiernym zawilgoceniem,Builder, 6, 90-93 (2014)

13. F.Frossel, (Osuszanie murów i renowacja piwnic, Wydawnictwo Polcen, Warszawa 2017) 